\title{
THE NGA-DOE GRANT TO EXAMINE CRITICAL ISSUES RELATED TO RADIOACTIVE WASTE AND MATERIALS DISPOSITION INVOLVING DOE FACILITIES
}

\author{
QUARTERLY REPORT
}

April-June 2001

\author{
Prepared by: \\ Ethan W. Brown \\ Policy Analyst \\ Natural Resources Policy Studies Division \\ Center for Best Practices \\ National Governors' Association
}

SEPTEMBER 2001

(DE-FG26-97FT34337) 


\section{Disclaimer}

This report was prepared as an account of work sponsored by an agency of the United States Government. Neither the United States Government nor any agency thereof, nor any of their employees, makes any warranty, express or implied, or assumes any legal liability or responsibility for the accuracy, completeness, or usefulness of any information, apparatus, product, or process disclosed, or represents that its use would not infringe privately owned rights. Reference herein to any specific commercial product, process, or service by trade name, trademark, manufacturer, or otherwise does not necessarily constitute or imply its endorsement, recommendation, or favoring by the United States Government or any agency thereof. The views and opinions of authors expressed herein do not necessarily state or reflect those of the United States Government or any agency thereof. 


\section{Abstract}

Through the National Governors' Association (NGA) project "Critical Issues Related to Radioactive Waste and Materials Disposition Involving DOE Facilities" NGA brings together Governors' policy advisors, state regulators, and DOE officials to examine critical issues related to the cleanup and operation of DOE nuclear weapons and research facilities. Topics explored through this project include:

- Decisions involving disposal of mixed, low-level, and transuranic (TRU) waste and disposition of nuclear materials.

- Decisions involving DOE budget requests and their effect on environmental cleanup and compliance at DOE facilities.

- Strategies to treat mixed, low-level, and transuranic (TRU) waste and their effect on individual sites in the complex.

- Changes to the FFCA site treatment plans as a result of proposals in the Department's Accelerating Cleanup: Paths to Closure plan and contractor integration analysis.

- Interstate waste and materials shipments.

- Reforms to existing RCRA and CERCLA regulations/guidance to address regulatory overlap and risks posed by DOE wastes.

The overarching theme of this project is to help the Department improve coordination of its major program decisions with Governors' offices and state regulators and to ensure such decisions reflect input from these key state officials and stakeholders.

This report summarizes activities conducted during the period from April 1, 2001 through June 30, 2001, under the NGA grant. The work accomplished by the NGA project team during the past three months can be categorized as follows:

- Continuing research and writing of draft segments for Long-Term Stewardship (LTS) of DOE Legacy Waste Sites: A State Handbook of Best Practices, an NGA publication for state policymakers that provides an overview of stewardship issues from the state perspective, including a review of current best practices;

- providing meeting materials, including agenda, background information, and presentations for the NGA Federal Facilities Task Force meeting with DOE on April 11-12, 2001 in Washington D.C.;

- facilitating NGA Federal Facilities Task Force meeting with DOE on April 11-12, 2001 in Washington D.C.; 
- continuing to update and add new materials to the NGA web page on the weapons complex cleanup program;

- researching cost estimation practices and financing arrangements for LTS measures within the context of the weapons complex;

- maintaining on-going communication between NGA Federal Facilities Task Force members regarding complex-wide integration issues and other areas of shared concern; and

- facilitating interactions between the states and DOE to develop a foundation for an ongoing substantive relationship between the Governors of key states and the Department. 


\section{Table of Contents}

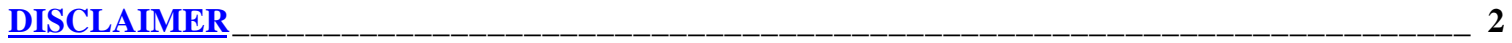

ABSTRACT

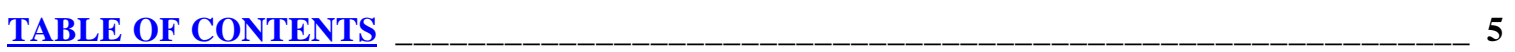

EXECUTIVE SUMMARY

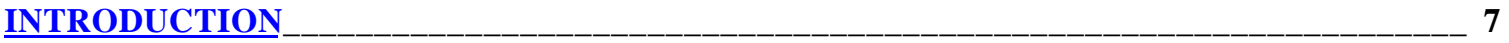

RESULTS AND DISCUSSION

STATE DIALOGUE _-_-_-_-_-_-_-_-_-_-_-_-_-_-_-_-_-_-_-_-_-_-_-_-_-_-_-_-_-_-_-_-_-_-_-_ 8

CONCLUSION _-_-_-_-_-_-_-_-_-_-_-_-_-_-_-_-_-_-_-_-_-_-_-_-_-_-_-_-_-_-_ 10 


\section{Executive Summary}

This report summarizes activities conducted during the period April 01, 2001-June 30, 2001, under the National Governors' Association (NGA) project, "Critical Issues Related to Radioactive Waste and Materials Disposition Involving DOE Facilities." The overarching theme of this project is to help the Department improve coordination of its major program decisions with Governors' offices and state regulators and to ensure such decisions reflect input from these key state officials and stakeholders.

NGA project team activities during this reporting period were focused on:

- facilitating interactions between the states and DOE;

- preparing for, and facilitating, April 11-12 NGA Federal Facilities Task Force meeting;

- providing formal feedback on DOE reports and initiatives;

- researching and writing draft segments of the NGA Long-Term Stewardship (LTS) of DOE Legacy Waste Sites: A State Handbook of Best Practices;

- researching cost estimation practices and financing arrangements for LTS measures within the context of the DOE complex;

- tracking ongoing efforts related to long-term stewardship; and

- continuing to update weapons complex cleanup web page located on NGA website.

NGA continues to work with DOE and to keep the states informed on a variety of activities and issues related to the DOE environmental management program. 


\section{Introduction}

Through DOE's grant to the National Governors' Association, NGA brings together Governors' policy advisors, state regulators, and DOE officials to examine critical issues related to the cleanup and operation of DOE's nuclear weapons and research facilities. Topics explored through this project include:

- Decisions involving disposal of mixed, low-level, and transuranic (TRU) waste and disposition of nuclear materials.

- Decisions involving DOE budget requests and their effect on environmental cleanup and compliance at DOE facilities.

- Strategies to treat mixed, low-level, and transuranic (TRU) waste and their effect on individual sites in the complex.

- Changes to the FFCA site treatment plans as a result of proposals in the Department's Accelerating Cleanup: Paths to Closure plan.

- Interstate waste and materials shipments.

- Long-term stewardship of DOE sites.

- Reforms to existing RCRA and CERCLA regulations/guidance to address regulatory overlap and risks posed by DOE wastes.

The overarching theme of this project is to help the Department improve coordination of its major program decisions with Governors' offices and state regulators and to ensure such decisions reflect input from these key state officials and stakeholders.

This report summarizes activities conducted during the quarter from April 1, 2001--June 30, 2001 under the NGA project. The work accomplished by the NGA project team during the three month period can be categorized as follows:

NGA project team activities during this reporting period were focused on:

- researching and writing draft segments for Long-Term Stewardship (LTS) of DOE Legacy Waste Sites: A State Handbook of Best Practices, an NGA publication for state policymakers that provides an overview of stewardship issues from the state perspective, including a review of current best practices;

- researching cost estimation practices and financing arrangements for LTS measures within the context of the DOE complex; 
- preparing meeting materials, including agenda, background information, and presentations for the NGA Federal Facilities Task Force meeting with DOE on April 11-12, 2001;

- facilitating NGA Federal Facilities Task Force meeting with DOE on April 11-12, 2001;

- providing DOE with Task Force feedback on LTS reports and guidance;

- continuing to update and add new materials to the NGA web page on the weapons complex cleanup program;

- disseminating other information pertaining to LTS issues across the complex;

- maintaining on-going communication between NGA Federal Facilities Task Force members regarding complex-wide integration issues and other areas of shared concern; and

- facilitating interactions between the states and DOE to develop a foundation for an ongoing substantive relationship between the Governors of key states and the Department.

NGA continues to work with DOE and keep the states informed on a variety of activities and issues within the DOE environmental management complex.

\section{Results and Discussion}

\section{State Dialogue}

Our State Dialogue activities during this reporting period were focused on:

- facilitating NGA Federal Facilities Task Force meeting on April 11-12, 2001;

- preparing and delivering Federal Facilities Task Force Collective Message to the U.S. Department of Energy, a letter from Task Force states on key cleanup and budget issues;

- reviewing DOE Draft Guidance on LTS and preparing letter summarizing Task Force response;

- facilitating Task Force review of NGA Federal Facilities Environmental Compliance policy (NR 8) and providing NGA Natural Resources Committee with background information pertaining to policy;

- continuing to expand and improve NGA web site;

- continuing to facilitate interaction among the states and between the states and DOE on a range of critical DOE complex concerns; and

- reviewing background information and tracking ongoing efforts related to longterm stewardship and continuing work on the NGA LTS Handbook 
The NGA project team continued to track developments involving ongoing issues for potential dialogue between states and DOE. The NGA project team also continued to facilitate dialogue among the states on the task force regarding issues of shared concern. Topics covered during project period included: the new administration's priorities for the cleanup program, long-term stewardship issues such as financial mechanisms and institutional control, DOE's cleanup budget, developments in state regulation and oversight, DOE's LTS documents and analysis, and a host of considerations relating to complex-wide integration.

We continued to work on the Long-Term Stewardship (LTS) of DOE Legacy Waste Sites: A State Handbook of Best Practices. The publication will address objectives and key state principles for LTS; the role of the states in LTS; designing robust LTS infrastructure, including funding mechanisms, record keeping and information management, and institutional control measures; detecting and remedying failure, research and development; and implementing a national LTS framework.

The handbook is being designed to provide states with a series of discrete issue papers as the work moves forward. The issue papers will briefly summarize key issues and their importance to states, along with options for addressing these areas of concern. Where state program examples exist, issues papers will draw from current work being done by states and the lessons-learned from this work. In cases were there are no well-developed state programs, issue papers will discuss options for solving problems presented to the states by LTS issues. Issue papers will be discussed and policy options will be debated by states before the final report is produced.

With assistance from Nevada Task Force members, we continue to maintain the LongTerm Stewardship web page. The website contains information about LTS activities being implemented across the complex. Primary users of this website include members of the NGA Federal Facilities Task Force. Other potential users include governor's staff; state environmental officials; consultants; members of DOE sponsored federal advisory boards; and others involved in policy development and regulatory oversight of DOE contaminated media and infrastructure.

We continued to research background materials and activities of other organizations related to long-term stewardship, and continued to engage the states in a dialogue concerning critical LTS issues.

We prepared materials for the NGA Federal Facilities Task Force meeting on April 1112, 2001, including background materials and presentations.

On April 27, 2001 we held a conference call with the NGA Federal Facilities Task Force to:

- continue the review of DOE's NDAA report on LTS;

- review DOE's draft guidance on LTS per the request of David Geiser, Acting Director, DOE Office of LTS ; and 
- begin review of NGA Federal Facilities Policy (NGA NR 8) at request of NGA Natural Resources Committee;

On May 8, 2001 we held a conference call with the NGA Federal Facilities Task Force to review the status of the budget, discuss the Governors' response to Secretary Abraham's letter regarding the cleanup program, and to update Task Force members on status of NGA and NAAG work on EM efficiencies.

The May 8, 2001 conference call was later joined by Patty Bubar, DOE Office of Integration. The Task Force and Ms. Bubar discussed avenues for increased and more frequent communication on integration issues. It was decided that the NGA would facilitate a monthly conference call between the Task Force and DOE on integration issues.

On May 31, 2001 the Task Force and DOE Office of Integration participated in a NGA facilitated conference call to discuss pressing issues relating to Remote Handled TRU waste.

On June 28, 2001 NGA facilitated a conference call between the Task Force and the DOE Office of Integration. The discussion focused on three areas: (1) DOE Audit report on Low-Level Waste; (2) GAO re-evaluation of low-level waste on-site disposal decisions; and (3) the DOE generator summit in Denver, CO. Jerry Boese of Ross \& Associates attended the DOE generator summit on behalf of NGA.

\section{Conclusion}

NGA will continue to work with DOE and will keep the states informed on a variety of activities and issues within the DOE environmental management program. 